\title{
Pioneering EBF2 remodels the brown fat chromatin landscape
}

\author{
Jiexin Wang and Peter Tontonoz \\ Department of Pathology and Laboratory Medicine and Molecular Biology Institute, David Geffen School of Medicine, University \\ of California at Los Angeles, Los Angeles, California 90272, USA
}

In this issue of Genes \& Development, Shapira and colleagues (pp. 660-673) outline mechanisms by which the brown fat transcription factor early B-cell factor 2 (EBF2) selectively activates brown lineage-specific gene expression. The investigators show that EBF2 interacts with and recruits a tissue-specific BAF chromatin remodeling complex to brown fat gene enhancers, thereby regulating chromatin accessibility. Their findings provide important insight into epigenetic regulation of adipocyte fate and thermogenic gene expression.

Mammals have different types of adipocytes that are specialized to either store energy (white fat) or dissipate it in the form of heat (brown and beige fat) (Rosen and Spiegelman 2014; Inagaki et al. 2016). The molecular mechanisms underlying the distinct gene expression signatures of these cell types are incompletely understood. In particular, the role of chromatin remodeling factors in brown/ beige adipocytes remains to be fully defined. Epigenetic chromatin changes-including DNA methylation, histone modification (methylation and acetylation), and alterations in chromatin accessibility-are important contributors to tissue-specific gene expression. Chromatin modifications generate unique DNA landscapes that affect the engagement of DNA-binding transcription factors, thereby facilitating context-specific promoter and enhancer activity (Ho and Crabtree 2010). At present, little is known about the cooperation between brown fatspecific transcription factors and chromatin remodeling proteins. A better understanding is also needed of the relationship between spatiotemporal changes in chromatin conformation and the recruitment of specific DNA-binding complexes. In this issue of Genes \& Development, Shapira et al. (2017) advance our understanding of these issues by linking the action of the thermogenic transcription factor early B-cell factor 2 (EBF2) with BAF chromatin remodeling complexes.

[Keywords: EBF2; DPF3; BAF chromatin remodeling complex; brown adipogenesis; UCP1]

Corresponding author: ptontonoz@mednet.ucla.edu

Article is online at http://www.genesdev.org/cgi/doi/10.1101/gad.299644. 117.
EBF2 was identified initially as a transcription factor that determines adipocyte fate by regulating $\operatorname{PPAR} \gamma$ binding at brown fat gene promoters (Rajakumari et al. 2013). EBF2 expression is a determinant of brown/beige preadipocyte identity and is indispensable for beige adipocyte development (Wang et al. 2014). Mice lacking EBF2 are unable to activate the thermogenic program in inguinal white adipose tissue (iWAT) in response to adrenergic stimulation. Conversely, transgenic expression of Ebf2 in adipose tissues robustly stimulates beige adipocyte formation (Stine et al. 2016). However, whether and how EBF2 affects chromatin remodeling at brown/beige adipose-specific enhancers have been unclear.

Shapira et al. (2017) used ChIP-seq (chromatin immunoprecipitation [ChIP] combined with high-throughput sequencing) analysis to show that EBF2 bound preferentially to enhancer regions of brown fat-specific genes. They further investigated the importance of EBF2 in gating the binding of other key transcriptional regulators. Importantly, they found that loss of EBF2 in brown adipose tissue (BAT) resulted in reduced PPAR $\gamma$ and RNA polymerase II occupancy and reduced levels of the activating histone mark $\mathrm{H} 3 \mathrm{~K} 27 \mathrm{ac}$ on brown fat-selective cis elements. In complementary studies, they identified genes differentially regulated between wild-type and Ebf2-deficient BAT by RNA sequencing (RNA-seq) and correlated their expression with ChIP-identified EBF2binding sites. Gene ontology analysis confirmed that EBF2-responsive genes were enriched for processes associated with brown fat thermogenic function, such as electron transport chain activity and oxidative metabolism.

Having established that EBF2 regulates chromatin accessibility, Shapira et al. (2017) then endeavored to define the chromatin modifiers with which EBF2 partners to regulate thermogenesis. ATP-dependent BAF (SWI/SNF) chromatin remodeling complexes are known to regulate gene expression in cooperation with developmental stageand tissue-specific transcription factors (Kadam and Emerson 2003). Each BAF complex contains one of two

(C) 2017 Wang and Tontonoz This article is distributed exclusively by Cold Spring Harbor Laboratory Press for the first six months after the full-issue publication date (see http://genesdev.cshlp.org/site/misc/ terms.xhtml). After six months, it is available under a Creative Commons License (Attribution-NonCommercial 4.0 International), as described at http://creativecommons.org/licenses/by-nc/4.0/. 
DNase catalytic components, BRG1 or BRM, and multiple noncatalytic regulatory subunits. To explore the possibility that EBF2 might engage BAF complexes to modulate chromatin structure, Shapira et al. (2017) first confirmed a physical interaction between EBF2 and BRG1 in mature brown adipocytes. They then examined the importance of the BAF complex in regulating the brown-selective transcriptional program. Since the regulatory subunits of BAF complexes tend to have tissue-specific expression, the investigators profiled the expression of a panel of subunits in BAT and iWAT. Interestingly, double PHD fingers 3 (DPF3) was found to be preferentially expressed in brown/beige adipocytes compared with white adipocytes.

The investigators next demonstrated through knockdown studies that DPF3 was required for brown-specific gene expression and respiratory activity in brown adipocytes as well as the beigeing process in white adipocytes. Using formaldehyde-assisted identification of regulatory elements (FAIRE), they further provided evidence that DPF3 determines chromatin accessibility at enhancer regions of brown lineage-specific genes, including Ucp1. Moreover, the absence of DPF3 was found to impair the recruitment of BRG1 to brown gene enhancers, thereby compromising their permissive chromatin state.

Finally, Shapira et al. (2017) determined that Dpf3 was a direct transcriptional target of EBF2, establishing the existence of a feed-forward mechanism. $D p f 3$ expression was shown to be linked with EBF2 levels in the cell. Furthermore, ChIP-seq analysis identified an EBF2-binding site within the first intron of $D p f 3$. Disrupting this EBF2 motif by CRISPR-Cas gene editing reduced $D p f 3$ mRNA and protein levels by $60 \%$ without affecting the brown adipogenic program, confirming that EBF2 regulates DPF3 expression independent of differentiation status.

Overall, Shapira et al. (2017) elucidate a regulatory cascade in which EBF2 activates expression of the chromatin reader DPF3 and simultaneously recruits DPF3-anchored BAF complexes to brown fat-selective enhancers, thereby increasing chromatin accessibility and gene expression. An important implication of the current findings is that EBF2 acts as a pioneer factor capable of accessing target genomic sites in a closed chromatin state, preceding the recruitment of chromatin remodelers. This possibility is supported by the finding that EBF2 binding to brown-specific enhancers did not depend on the presence of DPF3 and BRG1. A key goal for future studies will be to determine the exact mode by which BAF complexes are targeted specifically to BAT/beige gene enhancers. Although Shapira et al. (2017) provided evidence that EBF2 may precede BAF complex binding at brown fat-selective enhancers, it remains to be determined whether EBF2 plays this instructive role exclusively. It is also unclear whether additional signals direct BAF complexes to their target chromatin sites. Since the histone reader domain of DPF3 is critical for mediating EBF2-induced Ucp1 expression, it is possible that BAF complexes are capable of recognizing and docking at BAT/beige-specific enhancers independent of EBF2. Finally, it will be interesting to characterize DPF3 function in brown and beige fat in vivo with tissue-specific DPF3 knockout models.

\section{References}

Ho L, Crabtree GR. 2010. Chromatin remodelling during development. Nature 463: 474-484.

Inagaki T, Sakai J, Kajimura S. 2016. Transcriptional and epigenetic control of brown and beige adipose cell fate and function. Nat Rev Mol Cell Biol 17: 480-495.

Kadam S, Emerson BM. 2003. Transcriptional specificity of human SWI/SNF BRG1 and BRM chromatin remodeling complexes. Mol Cell 11: 377-389.

Rajakumari S, Wu J, Ishibashi J, Lim HW, Giang AH, Won KJ, Reed RR, Seale P. 2013. EBF2 determines and maintains brown adipocyte identity. Cell Metab 17: 562-574.

Rosen ED, Spiegelman BM. 2014. What we talk about when we talk about fat. Cell 156: 20-44.

Shapira SN, Lim H-W, Rajakumari S, Sakers AP, Ishibashi J, Harms MJ, Won K-J, Seale P. 2017. EBF2 transcriptionally regulates brown adipogenesis via the histone reader DPF3 and the BAF chromatin remodeling complex. Genes Dev (this issue). doi: $10.1101 / \mathrm{gad} .294405 .116$.

Stine RR, Shapira SN, Lim HW, Ishibashi J, Harms M, Won KJ, Seale P. 2016. EBF2 promotes the recruitment of beige adipocytes in white adipose tissue. Mol Metab 5: 57-65.

Wang W, Kissig M, Rajakumari S, Huang L, Lim HW, Won KJ, Seale P. 2014. Ebf2 is a selective marker of brown and beige adipogenic precursor cells. Proc Natl Acad Sci 111: 14466-14471. 


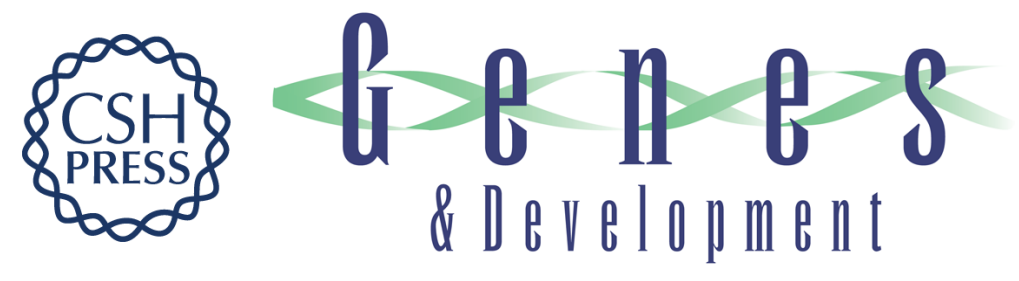

\section{Pioneering EBF2 remodels the brown fat chromatin landscape}

Jiexin Wang and Peter Tontonoz

Genes Dev. 2017, 31:

Access the most recent version at doi:10.1101/gad.299644.117

Related Content EBF2 transcriptionally regulates brown adipogenesis via the histone reader DPF3 and the BAF chromatin remodeling complex

Suzanne N. Shapira, Hee-Woong Lim, Sona Rajakumari, et al.

Genes Dev. April , 2017 31: 660-673

References This article cites 8 articles, 2 of which can be accessed free at:

http://genesdev.cshlp.org/content/31/7/632.full.html\#ref-list-1

Articles cited in:

http://genesdev.cshlp.org/content/31/7/632.full.html\#related-urls

Creative This article is distributed exclusively by Cold Spring Harbor Laboratory Press for the first Commons

License

six months after the full-issue publication date (see

http://genesdev.cshlp.org/site/misc/terms.xhtml). After six months, it is available under a Creative Commons License (Attribution-NonCommercial 4.0 International), as described at http://creativecommons.org/licenses/by-nc/4.0/.

Email Alerting Receive free email alerts when new articles cite this article - sign up in the box at the top Service right corner of the article or click here.

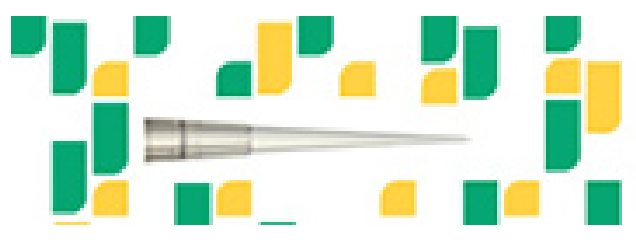

Focused on your science. 